\title{
Impact of $M E T$ amplification on gastric cancer: Possible roles as a novel prognostic marker and a potential therapeutic target
}

\author{
JEEYUN LEE $^{1 *}$, JIN WON SEO ${ }^{2 *}$, HYUN JUNG JUN ${ }^{1}$, CHANG-SEOK KI $^{3}$, SE HOON PARK ${ }^{1}$, \\ YOUNG SUK PARK ${ }^{1}$, HO YEONG LIM ${ }^{1}$, MIN GEW CHOI ${ }^{4}$, JAE MOON BAE ${ }^{4}$, \\ TAE SUNG SOHN ${ }^{4}$, JAE HYUNG NOH ${ }^{4}$, SUNG KIM ${ }^{4}$, HEY-LIM JANG ${ }^{5}$, JI-YOUN KIM ${ }^{5}$, \\ KYOUNG-MEE KIM ${ }^{2}$, WON KI KANG ${ }^{1}$ and JOON OH PARK ${ }^{1}$ \\ ${ }^{1}$ Division of Hematology-Oncology, Department of Medicine, Departments of ${ }^{2}$ Pathology, \\ ${ }^{3}$ Laboratory Medicine and ${ }^{4}$ Surgery, Samsung Medical Center, Sungkyunkwan University School \\ of Medicine, Seoul; ${ }^{5}$ Samsung Biomedical Research Institute, Seoul, Republic of Korea
}

Received December 17, 2010; Accepted February 7, 2011

DOI: 10.3892/or.2011.1219

\begin{abstract}
Identification of critical genes which play pivotal roles in controlling tumor growth and survival will establish the basis for developing therapeutic targets. With the aim of establishing personalized medicine for treatment of solid tumors, we focused on MET amplification in gastric cancer patients, given the extreme sensitivity to c-Met inhibitor in MET amplified gastric cancer cell lines. We tested MET amplification and activation of c-Met in various gastric cancer cell lines and tissue samples from 482 gastric cancer patients who underwent curative surgery. Gastric cancer cell lines with $M E T$ amplification by quantitative real-time PCR (qPCR) and FISH predicted sensitivity to PHA-665,752, a selective c-Met kinase inhibitor. Of the 472 patients who had DNA sample available for qPCR analysis, 100 patients $(21.2 \%)$ had a $M E T$ copy number greater than 4.0 copies and demonstrated poorer survival following curative surgery with statistical significance (5-year OS; 50.0 vs. 59.1\%; MET amplification (+) vs. MET amplification (-); $\mathrm{P}=0.0134)$. These results suggest that the increased $M E T$ copy number measured by qPCR plays an important role in determining prognosis in gastric cancer patients. However, the predictive role of $M E T$ amplification for treatment response should be further explored in upcoming clinical trials.
\end{abstract}

Correspondence to: Dr Joon Oh Park, Division of HematologyOncology, Department of Medicine, Samsung Medical Center, Sungkyunkwan University School of Medicine, 50 Irwon-dong Gangnam-gu, Seoul 135-710, Republic of Korea

E-mail: oncopark@skku.edu

${ }^{*}$ Contributed equally

Key words: gastric cancer, MET amplification, MET kinase inhibitors

\section{Introduction}

Gastric cancer is the leading cause of cancer death worldwide with the incidence of $18.9 / 100,000$ per year (1). The incidence of gastric cancer was estimated to be 934,000 cases, with $56 \%$ of the new cases occurring in East Asia (2). Gastric cancer accounts for $20.8 \%$ of all cancers in Korea according to the Central Tumor Registry data for 2002 (3). Although overall survival of gastric cancer has been enhanced owing to the application of national fiberoptic esophagogastroduodenoscopy (EGD) screening program in adults aged over 40 years in Korea, a large proportion of patients are still diagnosed at metastatic stage. The median survival time following cytotoxic chemotherapy is still less than 1 year and thus, metastatic gastric cancer remains a therapeutic challenge for medical oncologists. The role of molecularly targeted therapy has not been adequately explored in gastric cancer when compared to other common solid tumors such as non-small cell lung cancer, breast or colorectal cancer.

The $M E T$ oncogene encodes the receptor tyrosine kinase (RTK) for hepatocyte growth factor (HGF) and controls genetic programs leading to cell growth, invasion and protection from apoptosis (4). Although the definitive role of $M E T$ oncogene is yet to be determined in carcinogenesis of gastric cancer, overexpression and amplification of $c$-Met has been demonstrated in gastric cancer cell lines (5-9). In addition, approximately $10-20 \%$ of gastric cancer tissues and up to $40 \%$ of the scirrhous histological subtype were shown to harbor increased $M E T$ gene copy numbers $(6,10,11)$. Importantly, PHA-665,752, a selective c-Met kinase inhibitor showed significant reduction of established tumor mass in mouse xenografts with GTL16, a gastric cancer cell line with $>10$-fold MET amplification $(5,12)$. Another pivotal study showed that gastric cancer cells with $M E T$ amplification were extremely sensitive to PHA-665,752 and implicated a potential role of c-Met protein in developing theranostics in gastric cancer (13). Due to limited number of patients in previous studies, 
the predictive capacity of c-Met protein overexpression or $M E T$ amplification for survival in gastric cancer needs to be determined.

We undertook this study to assess the impact of c-Met overexpression, c-Met activation, and MET amplification on survival of gastric cancer patients.

\section{Materials and methods}

Patients and tissues. We have previously reported the outcome of 544 stage II-IV (M0) gastric cancer patients, who received adjuvant chemoradiation therapy after curative surgery (14). Of these patients and additional 23 stage IB patients who were included in our previous study, formalin-fixed paraffin-embedded primary tumor tissues were available from 482 patients. The postoperative adjuvant treatment adopted was the same as that used for the INT-0116 (SWOG9008) trial and the results were previously reported (15). All patients provided written informed consent according to the institutional guideline and the study was approved by the Institutional Review Board. The clinical and pathological features of the patients are shown in Table I. The median age was 54 (range 23-70) years. By Lauren classification, 29.9\% of patients had intestinal type. All patients received D2 or greater lymph node dissection and $34.3 \%$ of patients had stage IB or II. After a median follow-up duration of 110.7 months (84.9155.4 months), a 5-year overall survival (OS) rate was $57.7 \%$ and a 5-year disease-free survival (DFS) rate was $56.4 \%$.

Cell culture and cell growth assay. Human gastric carcinoma cells, MKN-1, MKN-45, MKN-74, N87 SNU-1, SNU-5, SNU-484, SNU-638 and SNU-668 cells were purchased from the Korean Cell Line Bank (Seoul, Korea). YCC-2, YCC-3 and YCC-7 were kindly provided by Dr Hyun Cheol Chung (Yonsei Cancer Center, Seoul, Korea). YCC-2, YCC-3 and YCC-7 were maintained in DMEM (Gibco-BRL, Carlsbad, CA) supplemented with $10 \%$ heat-inactivated FBS, 100 units/ml penicillin, 100 units/ml streptomycin, and $2 \mathrm{mM}$ glutamine; the others were cultured in RPMI-1640 medium (Gibco-BRL) supplemented with $10 \%$ heat-inactivated FBS, 100 units/ml penicillin, 100 units $/ \mathrm{ml}$ streptomycin, and $2 \mathrm{mM}$ glutamine. All cells were incubated in a humidified atmosphere contained $5 \% \mathrm{CO}_{2}$ at $37^{\circ} \mathrm{C}$.

Growth and inhibition of growth were assessed by the 5-(3carboxymethoxyphenyl)-2-(4-sulfophenyl)-2H-tetrazolium (MTS) assay according to previously established methods (16). PHA-665,752 was purchased from Tocris Bioscience (Ellisville, MO). Stock solution of $10 \mathrm{mM}$ was prepared in DMSO and stored at $-20^{\circ} \mathrm{C}$.

Antibodies and Western blotting. Cells grown under the previously specified conditions were lysed in the following lysis buffer composition: $20 \mathrm{mM} / 1$ Tris (pH 7.4), $150 \mathrm{mM} / 1 \mathrm{NaCl}$, $1 \% \mathrm{NP} 40,10 \%$ glycerol, $1 \mathrm{mM} / 1$ EDTA, $1 \mathrm{mM} / 1$ EGTA, $5 \mathrm{mM} / 1$ sodium pyrophosphate, $50 \mathrm{mM} / 1 \mathrm{NaF}, 10 \mathrm{nM} / 1$ $\beta$-glycerophosphate, $1 \mathrm{mM} / 1$ sodium vanadate, $0.5 \mathrm{mM} / 1 \mathrm{DTT}$, $4 \mu \mathrm{g} / \mathrm{ml}$ leupeptin, $4 \mu \mathrm{g} / \mathrm{ml}$ pepstatin, $4 \mu \mathrm{g} / \mathrm{ml}$ apoprotein, and $1 \mathrm{mM} / 1$ phenylmethylsulfonyl fluoride. Lysates were centrifuged at $16,000 \times \mathrm{g}$ for $5 \mathrm{~min}$ at $4^{\circ} \mathrm{C}$. The supernatant was used for subsequent procedures. Western blot analyses were
Table I. Patient characteristics.

\begin{tabular}{lc}
\hline Characteristics & $\mathrm{N}=482(\%)$ \\
\hline Age (year) median, range & $54,23-70$ \\
$\leq 60$ & $357(74.1)$ \\
$>60$ & $125(25.9)$ \\
Sex & \\
Male & $324(67.2)$ \\
Female & $158(32.8)$
\end{tabular}

Type of gastrectomy

Subtotal gastrectomy $205(42.5)$

Total gastrectomy $277(57.5)$

Location of tumor

Distal $1 / 3 \quad 230(47.7)$

$\begin{array}{ll}\text { Middle } 1 / 3 & 210(43.6)\end{array}$

Proximal $1 / 3 \quad 34(7.1)$

Diffuse $\quad 8(1.7)$

Histology

Well differentiated tubular adenocarcinoma $\quad 48$ (9.9)

Moderately differentiated tubular adenocarcinoma 87 (18.0)

Poorly differentiated tubular adenocarcinoma 255 (52.9)

Signet ring cell carcinoma $73(15.1)$

Mucinous adenocarcinoma $11(2.3)$

Papillary adenocarcinoma $4(0.8)$

Adenosquamous carcinoma $1(0.2)$

Hepatoid adenocarcinoma $1(0.2)$

Others

$2(0.4)$

Lauren classification

Intestinal

144 (29.9)

Diffuse

336 (69.7)

Indeterminate

2 (0.4)

T stage

T1

$21(4.4)$

$\mathrm{T} 2$

$243(50.4)$

196 (40.7)

22 (4.6)

T4

$30(6.2)$

221 (45.9)

138 (28.6)

93 (19.3)

N3
209 (43.4)

108 (22.4)

\begin{tabular}{lc} 
AJCC stage & \\
IB & $21(4.4)$ \\
II & $144(29.9)$ \\
III & $209(43.4)$ \\
IV (M0) & $108(22.4)$ \\
\hline
\end{tabular}

performed according to the antibody manufacturer's recommendations. Antibody binding was detected using an enhanced chemiluminescence system (Perkin-Elmer, Waltham, MA). 
Anti-Met and anti-phospho-Met antibodies were from Cell Signaling Technology (Beverly, MA). Anti-phosphotyrosine (4G10) antibody was from Upstate Biotechnology (Lake Placid, NY).

Quantitative real-time PCR ( $P$ PCR). The MET and MTHFR (endogenous control) levels were evaluated using the following primers and methods previously published (17). MET-sense: 5'-CCA TCC AGT GTC TCC AGA AGT G-3'; MET-antisense: 5'-TTC CCA GTG ATA ACC AGT GTG TAG-3'; $M T H F R$-sense: 5'-CCA TCT TCC TGC TGC TGT AAC TG-3'; MTHFR-anti-sense: 5'-GCC TTC TCT GCC AAC TGT CC-3'. Genomic DNA (20 ng) was amplified for 40 cycles $\left(15 \mathrm{sec} 95^{\circ} \mathrm{C}, 60 \mathrm{sec} 60^{\circ} \mathrm{C}\right)$ in a ABI 7500 real-time PCR system (Applied Biosystems, Foster City, CA), using the QuantiTect SYBR-Green PCR kit (Qiagen, Valencia, CA) and $400 \mathrm{nM}$ primers. For all patients, triplicate cycle time $\left(\mathrm{C}_{\mathrm{T}}\right)$ values were averaged. Fold changes were calculated using the equation $2^{-\Delta \Delta \mathrm{CT}}$, where $\Delta \Delta \mathrm{CT}=\left[\mathrm{C}_{\mathrm{T}}(\mathrm{MET})\right.$ sample - $\mathrm{C}_{\mathrm{T}}(\mathrm{MTHFR})$ sample $]-\left[\mathrm{C}_{\mathrm{T}}(\mathrm{MET})\right.$ reference DNA - $\mathrm{C}_{\mathrm{T}}$ (MTHFR)reference DNA]. MET amounts were interpolated from the standard curves and normalized to MTHFR amounts. Normal DNAs from non-malignant gastric tissues and normal blood lymphocytes of healthy volunteers were used as reference DNAs for each PCR reaction. We also performed qPCR analysis using TaqMan primers which are directed at exon 2 of $M E T$ and have been previously described $(13,16)$. The results of the relative copy number for MET by two different methods were not different in the gastric cancer cell line and gastric cancer tissues (data not shown). We also carried out corresponding fluorescent in situ hybridization (FISH) on these specimens.

Immunohistochemistry. Tissue microarray (TMA) blocks were sectioned with $4 \mu \mathrm{m}$ thickness. Immunohistochemical study was performed using the streptavidin-biotin complex method and TechMate ${ }^{\mathrm{TM}} 1000$ automated staining system (DakoChemmate, Glostrup, Denmark). Primary antibodies used and working dilutions employed were as follows; c-Met (24H2, Cell Signaling Technology; 1:100) phospho-Met (pY1349, Cell Signaling Technology; 1:100). Deparaffinized sections were treated with $3 \%$ hydrogen peroxide in methanol for $10 \mathrm{~min}$ to inhibit endogenous peroxidase. Sections were immersed in $0.01 \mathrm{M}$ citrate buffer ( $\mathrm{pH}$ 6.0) and heated in a pressure cooker for $30 \mathrm{~min}$. Sections were then incubated with primary antibody for $50 \mathrm{~min}$ at room temperature. Each section was treated sequentially with biotinylated secondary antibody (anti-mouse immunoglobulin) and streptavidinperoxidase complex (DakoChemmate).3,3'-diaminobenzidine tetrahydrochloride was used as a chromogen, and then Mayer's hematoxylin counterstain was applied. Negative controls (isotype-matched irrelevant antibody) were run simultaneously. The results of staining were evaluated by two independent pathologists (S.J.W. and K.M.K.), who were blinded to the clinical data and the difference in interpretation was resolved by consensual agreement. Total Met-staining cells exhibited a combined membranous and cytoplasmic pattern, whereas phosphorylated Met-staining cells showed nuclear staining in addition to the combined membranous and cytoplasmic pattern. For assessment of the positivity of immunostaining for each section, the staining intensity was graded on the following scale: 0 , no staining; 1 , weak staining; 2 , moderate staining; and 3, intense staining, and nuclear staining of phospho-Met in $>5 \%$ of tumor cells was regarded as positive. Positive cells were counted by monitoring at least 1,000 cancer cells from more than five high power fields where positive cells were present at a relatively uniform density.

FISH. FISH was performed according to the established protocol using a D7S522 probe and chromosome 7 centromere probe (CEP7) purchased from Vysis (Des Plaines, IL) (16). Four micron $(4 \mu \mathrm{m})$ tumor sections generated from TMA blocks were pretreated by deparaffinizing in xylene and dehydrating in ethanol. The sections were immersed in Tris-base and EDTA (TE), washed in phosphate-buffered saline (PBS), and then treated with Digest-All (Zymed, San Francisco, CA). Sections were then fixed with formalin and dehydrated in ethanol. After co-denaturation of the tissue and the probe mixture (D7S522 and CEP7) at $70^{\circ} \mathrm{C}$ for $3 \mathrm{~min}$, the sections were hybridized at $37^{\circ} \mathrm{C}$ for $48-72 \mathrm{~h}$, washed with sodium citrate and Tween-20 containing buffers and counterstained with DAPI. One hundred cells from each TMA core were analyzed and the number of D7S522 and CEP7 signals determined.

Statistical analyses. Disease-free survival (DFS) was defined as the time from surgery to the first relapse of cancer, or death of any cause. Overall survival (OS) was calculated from the date of surgery to the date of death. OS and DFS were calculated using the Kaplan-Meier method. Correlation analyses were performed using the two sided $\chi^{2}$ test or Fisher's exact test. Differences in disease-free and overall survival were compared using log-rank tests and Cox proportional hazard analysis. P-value $<0.05$ was considered statistically significant.

\section{Results}

MET amplification and constitutive activation in human gastric cancer cells. Immunoblotting analysis showed heterogeneous phosphotyrosine and various levels of c-Met expression in a panel of gastric cancer cell lines. Immunoblotting using phospho-Met antibodies against Y1349 showed constitutive phosphorylation of the receptor in cells with MET amplification, whereas cells without amplification had low levels of c-Met phosphorylation (Fig. 1A). Analysis of the gastric cancer cell lines using qPCR identified the increased $M E T$ gene copy number which predicted sensitivity to PHA-665,752 (Fig. 1B). We also confirmed MET amplification in SNU-5, SNU-638 and MKN-45 by FISH.

Correlation between MET amplification and clinical variables. Of the 472 patients who had DNA sample available for qPCR analysis, 100 (21.2\%) of the patients had MET copy number $>4.0$. Of the 100 patients who had amplified $M E T$ gene, 84 patients had 4.0-6.0 copies, 10 patients 6.0-8.0 copies, and 6 patients had 8.0-16 copies. The clinical features between the patients with MET amplification and those without amplification were not significantly different 


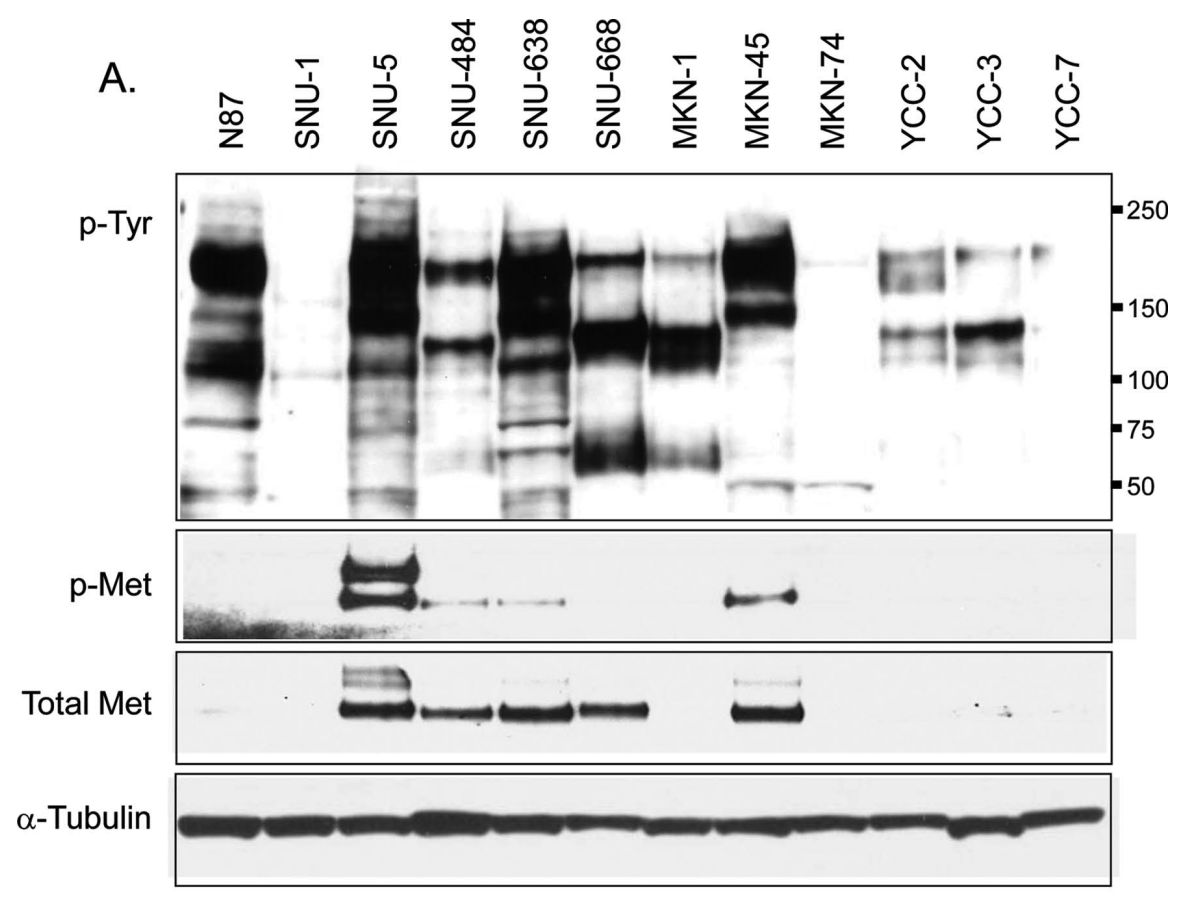

B.

Copy No.

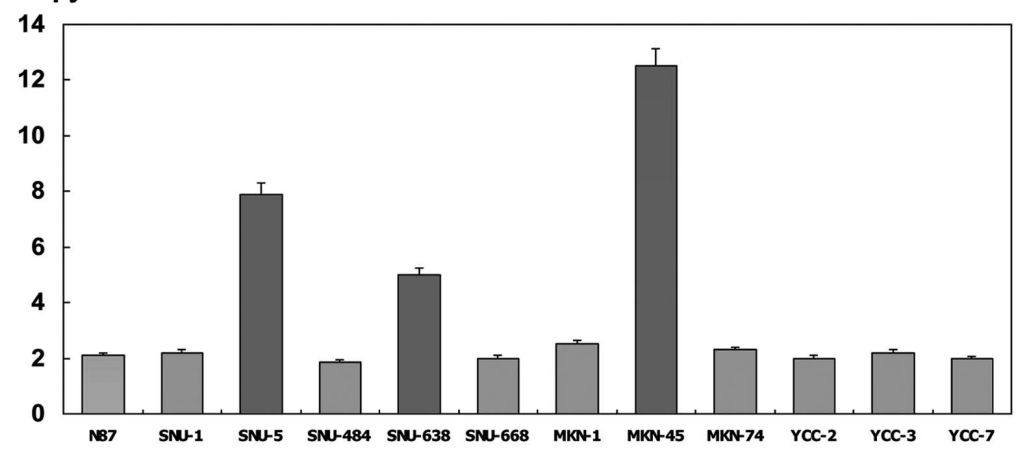

$I_{50}(\mu \mathrm{M})>10 \quad 3.2 \quad 0.05>10 \quad 0.3 \quad 5.3>10 \quad 0.04>10>10>10>10$

Figure 1. Immunoblot analysis showing heterogeneous phosphotyrosine and various levels of c-Met expression in a panel of gastric cancer cell lines (A). Analysis of the gastric cancer cell lines by using qPCR identified that increased MET gene copy number predicted sensitivity to PHA-665,752, a selective c-Met kinase inhibitor (B).

(Table II). There was a trend toward more advanced $\mathrm{N}$ stage in patients with $M E T$ amplification, but there was no statistical significance $(\mathrm{P}=0.060)$.

Correlation between MET amplification, $c$-Met protein expression and c-Met activation. In order to determine the most influential and important factors reflective of c-Met status, we tested MET amplification along with c-Met protein expression and c-Met activation which were evaluated by immunohistochemical staining against c-Met protein and phospho-Met (pY1349), respectively. In total, 452 specimens were interpretable for c-Met protein expression and activated phosphorylated Met expression. The representative immunohistochemical staining for activated c-Met is shown in Fig. 2A-F. Of the 103 tumor samples with c-Met activation identified by staining against phospho-Met (pY1349), $30(29.1 \%)$ had MET amplification ( $\geq 4$ copies) $(\mathrm{P}=0.026$, Table III). In contrast, a concordance rate between c-Met protein expression and $M E T$ amplification was only $17.9 \%$ (32 of 179 samples) (Table III). Of the 472 samples evaluated, FISH analysis was successfully performed in 309 tissue samples (Fig. 2G). Thirty-one patients (10.0\%) exhibited FISH positivity for $M E T$ gene and the concordance rate between MET amplification assessed by qPCR and FISH was only $58.1 \%$; 18 of $31 \mathrm{FISH}(+)$ patients had MET amplification (data not shown).

Impact of MET amplification on recurrence and survival. We performed survival analyses according to the c-Met status (Fig. 3). Gastric cancer patients with MET amplification had a significantly shorter disease-free survival following curative surgery (5-year DFS; 49.0 vs. 57.7\%; MET amplification (+) vs. MET amplification (-); $\mathrm{P}=0.0216)$. Moreover, gastric cancer patients with $M E T$ amplification demonstrated poorer survival following curative surgery with statistical significance (5-year OS; 50.0 vs. 59.1\%; MET amplification (+) vs. 
Table II. Clinical features and MET amplification.

\begin{tabular}{|c|c|c|c|c|}
\hline & \multirow[b]{2}{*}{$\begin{array}{l}\text { No. of cases } \\
(\mathrm{N}=472)(\%)\end{array}$} & \multicolumn{3}{|c|}{ MET amplification } \\
\hline & & $\begin{array}{l}M E T \text { copy No. } \geq 4.0 \\
(\mathrm{~N}=100)(\%)\end{array}$ & $\begin{array}{l}\text { MET copy No. }<4.0 \\
(\mathrm{~N}=372)(\%)\end{array}$ & $\mathrm{P}$-value \\
\hline \multicolumn{5}{|l|}{ Age } \\
\hline$\leq 60$ & $349(73.9)$ & $81(81.0)$ & $268(72.0)$ & \multirow[t]{2}{*}{0.070} \\
\hline$>60$ & $123(26.1)$ & $19(19.0)$ & $104(28.0)$ & \\
\hline \multicolumn{5}{|l|}{ Lauren classification } \\
\hline Intestinal & $142(30.2)$ & $28(28.0)$ & $114(30.6)$ & \multirow[t]{2}{*}{0.658} \\
\hline Diffuse & $328(69.8)$ & $72(72.0)$ & $256(68.8)$ & \\
\hline \multicolumn{5}{|l|}{ Sex } \\
\hline Male & $316(66.9)$ & $63(63.0)$ & $253(68.0)$ & \multirow[t]{2}{*}{0.344} \\
\hline Female & $156(33.1)$ & $37(37.0)$ & $119(32.0)$ & \\
\hline \multicolumn{5}{|l|}{ Tumor infiltration } \\
\hline $\mathrm{T} 1 / \mathrm{T} 2$ & $260(55.1)$ & $49(49.0)$ & $211(56.7)$ & \multirow[t]{2}{*}{0.168} \\
\hline $\mathrm{T} 3 / \mathrm{T} 4$ & $212(44.9)$ & $51(51.0)$ & $161(43.3)$ & \\
\hline \multicolumn{5}{|l|}{ AJCC stage } \\
\hline IB-II & $164(34.7)$ & $32(32.0)$ & $132(35.5)$ & \multirow[t]{2}{*}{0.516} \\
\hline IIA-IV & $308(65.3)$ & $68(68.0)$ & $240(46.5)$ & \\
\hline \multicolumn{5}{|l|}{ Lymph node metastasis } \\
\hline $\mathrm{N} 0 / \mathrm{N} 1$ & $247(52.3)$ & $44(44.0)$ & $203(54.6)$ & \multirow[t]{2}{*}{0.060} \\
\hline $\mathrm{N} 2 / \mathrm{N} 3$ & $225(47.7)$ & $56(56.0)$ & $169(45.4)$ & \\
\hline \multicolumn{5}{|c|}{ Histological grade (adenocarcinoma only) } \\
\hline $\begin{array}{l}\text { Well differentiated/ } \\
\text { moderately differentiated }\end{array}$ & $133(34.8)$ & $27(33.3)$ & $106(35.2)$ & \multirow[t]{2}{*}{0.752} \\
\hline Poorly differentiated & $249(65.2)$ & $54(66.7)$ & $195(64.8)$ & \\
\hline
\end{tabular}

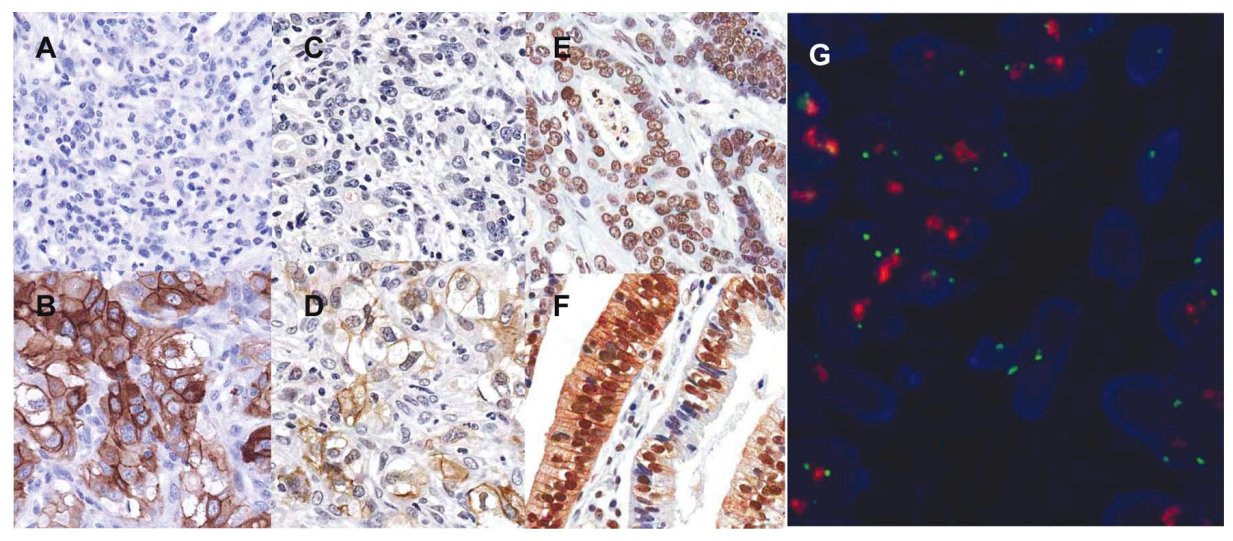

Figure 2. Immunohistochemical detection of the total Met (B, membranous and cytoplasmic staining) and phospho-Met [(D), membranous and cytoplasmic staining; (E), nuclear staining; (F), membranous, cytoplasmic and nuclear staining] on TMA. Negative control is seen in (A and C) (X 200). MET amplification is detected in a gastric cancer tissue (G). Dual-color FISH [CEP7 (green)/D7S522 (red)] was performed on TMA from a gastric cancer patient.

MET amplification (-); $\mathrm{P}=0.0134$, Fig. 3A). Using backward stepwise Cox proportional hazards regression modeling, following variables were tested: age $(\leq 60$ vs. $>60)$, Lauren classification, stage (IB/II vs. III/IVM0), MET amplification, c-Met FISH, and c-Met protein activation. For overall survival in all patients, $M E T$ amplification $[\mathrm{P}=0.022$, hazard ratio $(\mathrm{HR})=1.601,95 \% \mathrm{CI}, 1.078,2.380)$, c-Met protein activation
$(\mathrm{P}=0.013,(\mathrm{HR})=2.173,95 \% \mathrm{CI}, 1.098,4.301]$ and advanced stage $[\mathrm{P}=<0.0001$, hazard ratio $(\mathrm{HR})=2.871,95 \% \mathrm{CI}, 1.905$, 4.327] predicted poor survival with statistical significance at multivariate level.

In total, 30 patients had MET amplification with c-Met protein activation while 283 patients did not harbor $M E T$ amplification and no c-Met protein activation in the series. 
Table III. Correlation between MET amplification, c-Met protein expression and c-Met activation.

\begin{tabular}{|c|c|c|c|c|c|c|}
\hline & \multicolumn{3}{|c|}{ c-Met protein expression } & \multicolumn{3}{|c|}{ c-Met activation } \\
\hline & Positive (N=179) & Negative $(\mathrm{N}=273)$ & P-value & Positive $(\mathrm{N}=103)$ & Negative $(\mathrm{N}=349)$ & P-value \\
\hline \multicolumn{7}{|c|}{ MET amplification } \\
\hline$\geq 4$ copies & $32(17.9)$ & $64(23.4)$ & 0.157 & $30(29.1)$ & $66(18.9)$ & 0.026 \\
\hline$<4$ copies & $147(82.1)$ & $209(76.6)$ & & $73(70.9)$ & $283(81.1)$ & \\
\hline
\end{tabular}

A

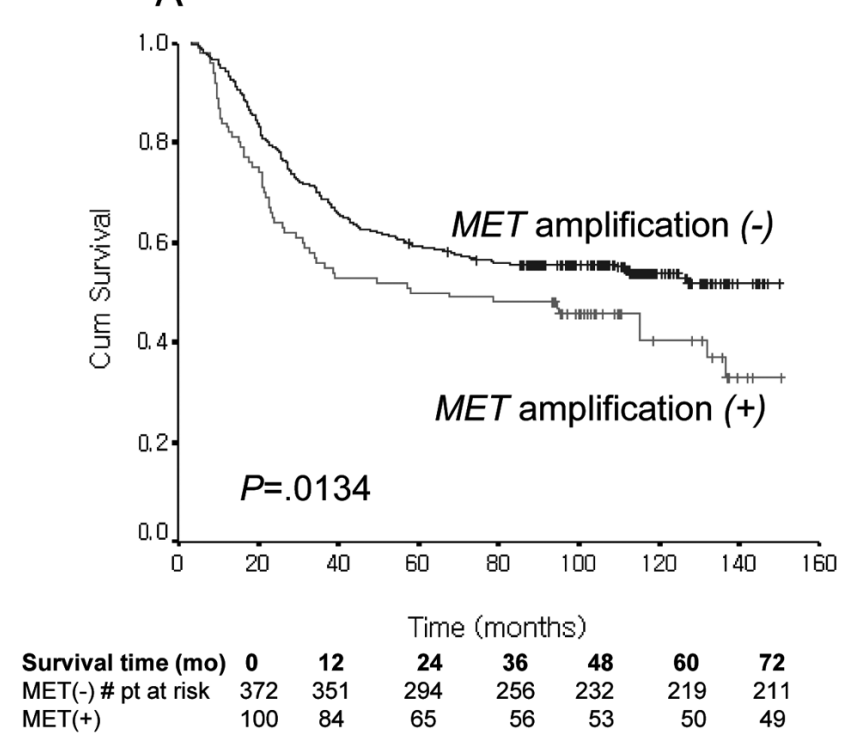

B

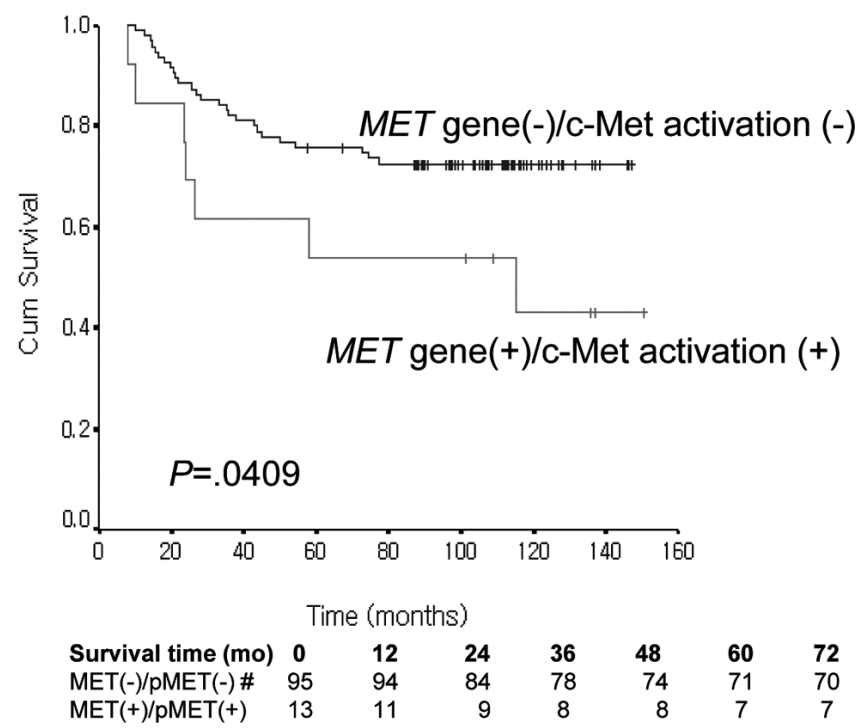

Figure 3. Overall survival curves according to the MET amplification (A) and c-Met activation status (B).

In subgroup analyses, there was a trend toward poorer prognosis in the subset of patients with MET amplification and c-Met protein activation $(\mathrm{n}=30)$ when compared with those without MET amplification or c-Met protein activation ( $\mathrm{n}=283$ ) (5-year OS; 50.0 vs. 57.9\%, respectively; $\mathrm{P}=0.1317$ ). In localized disease (stage I/II), however, concurrent detection MET amplification with c-Met protein activation significantly predicted worse survival when compared with those without the two variables with statistical significance (5-year OS; 53.8 vs. $75.9 \%$, respectively; $\mathrm{P}=0.0409$, Fig. 3B).

\section{Discussion}

Recently, gastric cancer cells with high-level stable chromosomal amplification of the growth factor receptor $M E T$ were shown to be extraordinarily susceptible to the c-Met selective inhibitor PHA-665752 (13). Identification of critical genes which play pivotal role in controlling tumor growth and survival will establish the basis for developing therapeutic targets. The most successful example of such identification of critical genes leading to overall improvement in treatment outcome is amplification of a locus on chromosome $17 \mathrm{q}$ which targets the HER2 growth factor receptor and the use of trastuzumab in HER2 amplified breast cancer. To establish personalized medicine for the treatment of solid tumors, we focused on $M E T$ amplification in gastric cancer patients given the extreme sensitivity to c-Met inhibitor in MET amplified gastric cancer cell lines (13).

We performed qPCR to determine the status of $M E T$ amplification in DNA samples from curatively resected gastric cancer tissues. Of the 472 patients who had DNA sample available for qPCR analysis, $100(21.2 \%)$ of the patients had $M E T$ amplification. Of note, gastric cancer patients with MET amplification had a significantly shorter disease-free survival (5-year DFS; 49.0 vs. 57.7\%; MET gene amplification (+) vs. MET amplification (-); $\mathrm{P}=0.0216)$ and poorer survival following curative surgery with statistical significance (5-year OS; 50.0 vs. $59.1 \%$; MET gene amplification (+) vs. MET gene amplification (-); $\mathrm{P}=0.0134$, Fig. 3).

Given the fact that MET amplification may not always lead to c-Met activation, we performed parallel analyses on c-Met activation and total c-Met protein expression using immunohistochemical staining against phosphorylated c-Met (pY1349) and c-Met protein, respectively. Approximately 30\% of the tumor samples with MET amplification concordantly showed c-Met protein activation while $18 \%$ demonstrated concomitant c-Met protein expression. Moreover, about one third $(66$ of $181,36.5 \%)$ of the c-Met $(+)$ tumor samples were 
associated with c-Met protein activation (data not shown). It has been reported that some cell lines with HER2 amplification (JIMT-1 breast cancer cell line) or activating EGFR mutation (11-18 lung cancer cell line) without protein expression showed resistance to specific targeted agents $(18,19)$. However, there are no in vitro models reported in regards to MET amplification without protein expression. Therefore, the clinical implication of this phenomenon should be further investigated. Nevertheless, the MET amplification status, not the activation status of c-Met protein was significantly influential on disease-free survival or overall survival in gastric cancer patients. In addition, the activation status of c-Met protein did not considerably influence survival (5-year OS; 56.7 vs. $59.6 \%$; activated c-Met protein (+) vs. (-); $\mathrm{P}=0.7512)$ The form of c-Met status that has clinical implication as predictive factor for treatment response to c-Met inhibitor needs to be further investigated in several ongoing early phase trials using the c-Met inhibitor. Interestingly, gastric cancer patients with $M E T$ amplification with concomitant c-Met protein activation demonstrated the worst outcome in subgroup analyses, especially in localized gastric cancer (Fig. 3B). c-Met inhibitors have shown promising results as anti-cancer therapy in phase I trials (20). In addition, an interim analysis of phase II study on 18 evaluable gastric cancer patients demonstrated that c-Met inhibitor (GSK089) was feasible with manageable toxicities and 8\% MET amplification rate (21). We plan to investigate whether treatment with c-Met inhibitor will actually confer survival benefit in this particular subset of patients.

Because a large-scaled analysis on c-Met status has not been performed in gastric cancer tissues or DNA samples, the cut-off value for MET amplification or c-Met protein expression and/or activation has not been standardized yet. Based on our experience, the FISH analysis was less feasible when compared with qPCR in assessing the MET amplification status. Of the 472 samples, only 309 samples yielded adequate FISH results for interpretation and of those, only 31 patients (10\%) demonstrated MET amplification by FISH. The relatively low levels of concordance between MET amplification by qPCR and the FISH results might be due to tumor heterogeneity. TMA blocks were made by taking 2-mm sized core biopsies from individual formalin fixed paraffinembedded (FFPE) gastric cancer tissues whereas genomic DNA for qPCR was prepared from FFPE sections following dissection of tumor to obtain sufficient tumor cell content. To test the tumor heterogeneity, therefore we repeated FISH analysis in selected cases with available tissue specimens.

Considerable attention has been focused on the role of MET amplification in tumorigenesis and in resistance mechanism to tyrosine kinase inhibitor since Engelman et al reported that MET amplification induced resistance to gefitinib in a gefitinib-sensitive lung cancer cell line and a c-Met tyrosine kinase inhibitor (PHA-665,752) restored gefitinib sensitivity (16). Since the molecular targeted therapy has been less extensively studied in gastric cancer as compared to non-small cell lung cancer, the role of MET amplification in such context needs to be defined in gastric cancer as well.

Taken together, we showed for the first time that MET is amplified in both cell lines and tumor tissues from gastric cancer patients. Importantly, MET amplification measured by qPCR was associated with shorter DFS and poorer OS but not c-Met protein overexpression or c-Met protein activation. Thus, MET amplification should be performed in addition to immunohistochemical studies for c-Met overexpression and c-Met activation (phosphorylated c-Met protein) as correlative analyses in clinical trials incorporating c-Met inhibitors. These studies may uncover a predictive role of MET amplification for treatment response, which should be also explored further as a novel therapeutic target in clinical trials.

\section{Acknowledgements}

The authors thank Dr Yoon-La Choi for technical advice and helpful discussion. Grant Support: this study was supported by Samsung Biomedical Research Institute Grant CA8-213-1 (J.O.P), IN-SUNG Foundation for Medical Research Grant CA7831 (W.K.K), and Basic Science Research Program through the National Research Foundation of Korea NRF2009-0074138 (J.O.P).

\section{References}

1. Cunningham D, Jost LM, Purkalne G and Oliveira J: ESMO Minimum Clinical Recommendations for diagnosis, treatment and follow-up of gastric cancer. Ann Oncol 16 (Suppl.) 1: i22-i23, 2005.

2. Inoue $M$ and Tsugane S: Epidemiology of gastric cancer in Japan. Postgrad Med J 81: 419-424, 2005.

3. Bae JM WY, Jung KW and Park JG: Annual report of the Korea Central Cancer Registry Program 2000: based on registered data from 131 hospitals. Cancer Res Treat 34: 77-83, 2002.

4. Corso S, Comoglio PM and Giordano S: Cancer therapy: can the challenge be MET? Trends Mol Med 11: 284-292, 2005.

5. Ponzetto C, Giordano S, Peverali F, Della Valle G, Abate ML, Vaula $\mathrm{G}$ and Comoglio PM: c-met is amplified but not mutated in a cell line with an activated met tyrosine kinase. Oncogene 6: 553-559, 1991.

6. Kuniyasu H, Yasui W, Kitadai Y, Yokozaki H, Ito H and Tahara E: Frequent amplification of the c-met gene in scirrhous type stomach cancer. Biochem Biophys Res Commun 189: 227-232, 1992.

7. Nakajima M, Sawada H, Yamada Y, Watanabe A, Tatsumi M, Yamashita J, Matsuda M, Sakaguchi T, Hirao T and Nakano H: The prognostic significance of amplification and overexpression of c-met and c-erb B-2 in human gastric carcinomas. Cancer 85: 1894-1902, 1999.

8. Inoue T, Kataoka H, Goto K, Nagaike K, Igami K, Naka D, Kitamura N and Miyazawa K: Activation of c-Met (hepatocyte growth factor receptor) in human gastric cancer tissue. Cancer Sci 95: 803-808, 2004

9. Huang TJ, Wang JY, Lin SR, Lian ST and Hsieh JS: Overexpression of the c-met protooncogene in human gastric carcinoma-correlation to clinical features. Acta Oncol 40: 638-643, 2001.

10. Nessling M, Solinas-Toldo S, Wilgenbus KK, Borchard F and Lichter P: Mapping of chromosomal imbalances in gastric adenocarcinoma revealed amplified protooncogenes MYCN, MET, WNT2, and ERBB2. Genes Chromosomes Cancer 23: 307-316, 1998.

11. Sakakura C, Mori T, Sakabe T, Ariyama Y, Shinomiya T, Date K, Hagiwara A, Yamaguchi T, Takahashi T, Nakamura Y, Abe T and Inazawa J: Gains, losses, and amplifications of genomic materials in primary gastric cancers analyzed by comparative genomic hybridization. Genes Chromosomes Cancer 24: 299-305, 1999.

12. Christensen JG, Schreck R, Burrows J, Kuruganti P, Chan E, Le P, Chen J, Wang X, Ruslim L, Blake R, Lipson KE, Ramphal J, Do S, Cui JJ, Cherrington JM and Mendel DB: A selective small molecule inhibitor of c-Met kinase inhibits c-Met-dependent phenotypes in vitro and exhibits cytoreductive antitumor activity in vivo. Cancer Res 63: 7345-7355, 2003. 
13. Smolen GA, Sordella R, Muir B, Mohapatra G, Barmettler A, Archibald H, Kim WJ, Okimoto RA, Bell DW, Sgroi DC, Christensen JG, Settleman J and Haber DA: Amplification of MET may identify a subset of cancers with extreme sensitivity to the selective tyrosine kinase inhibitor PHA-665752. Proc Natl Acad Sci USA 103: 2316-2321, 2006.

14. Kim S, Lim DH, Lee J, Kang WK, MacDonald JS, Park CH, Park SH, Lee SH, Kim K, Park JO, Kim WS, Jung CW, Park YS Im YH, Sohn TS, Noh JH, Heo JS, Kim YI, Park CK and Park K: An observational study suggesting clinical benefit for adjuvant postoperative chemoradiation in a population of over 500 cases after gastric resection with D2 nodal dissection for adenocarcinoma of the stomach. Int J Radiat Oncol Biol Phys 63: 1279-1285, 2005.

15. Macdonald JS, Smalley SR, Benedetti J, Hundahl SA, Estes NC Stemmermann GN, Haller DG, Ajani JA, Gunderson LL, Jessup JM and Martenson JA: Chemoradiotherapy after surgery compared with surgery alone for adenocarcinoma of the stomach or gastroesophageal junction. N Engl J Med 345: 725-730, 2001

16. Engelman JA, Zejnullahu K, Mitsudomi T, Song Y, Hyland C, Park JO, Lindeman N, Gale CM, Zhao X, Christensen J, Kosaka T, Holmes AJ, Rogers AM, Cappuzzo F, Mok T, Lee C, Johnson BE, Cantley LC and Janne PA: MET amplification leads to gefitinib resistance in lung cancer by activating ERBB3 signaling. Science 316: 1039-1043, 2007.
17. Bean J, Brennan C, Shih JY, Riely G, Viale A, Wang L, Chitale D, Motoi N, Szoke J, Broderick S, Balak M, Chang WC, Yu CJ, Gazdar A, Pass H, Rusch V, Gerald W, Huang SF, Yang PC, Miller V, Ladanyi M, Yang CH and Pao W: MET amplification occurs with or without T790M mutations in EGFR mutant lung tumors with acquired resistance to gefitinib or erlotinib. Proc Natl Acad Sci USA 104: 20932-20937, 2007.

18. Nagy P, Friedlander E, Tanner M, Kapanen AI, Carraway KL, Isola $\mathbf{J}$ and Jovin TM: Decreased accessibility and lack of activation of ErbB2 in JIMT-1, a herceptin-resistant, MUC4-expressing breast cancer cell line. Cancer Res 65: 473-482, 2005.

19. Sakai K, Yokote H, Murakami-Murofushi K, Tamura T, Saijo N and Nishio K: Pertuzumab, a novel HER dimerization inhibitor, inhibits the growth of human lung cancer cells mediated by the HER3 signaling pathway. Cancer Sci 98: 1498-1503, 2007.

20. Eder JP, Heath L, Appleman L, Shapiro G, Wang D, Malburg L, Zhu AX, Leader T, Wolanski A and LoRusso P: Phase I experience with c-MET inhibitor XL880 administered orally to patients (pts) with solid tumors. J Clin Oncol, 2007 ASCO Annual Meeting Proc. Part. I. Vol 25, No. 18S (June 20 Suppl.): 3526, 2007.

21. Jhawer MP, Kindler HL, Wainberg ZA, et al: Preliminary activity of GSK1363089 (formerly XL880), a Dual c-MET/ VEGFR2 inhibitor, in poorly differentiated gastric cancer (PDGC): interim results of a multicenter phase II study. 2008 ASCO Annual Meeting Proc. J Clin Oncol 26 (18S): abs. 4572, 2008. 